\title{
OPENNESS AND CLOSEDNESS FOUR CATEGORIES OF CLOSURIZATION IN MODERN ARABIC FICTION
}

\author{
Ibrahim Taha
}

HAIFA

The discussion of the four categories of ending and closure in modern Arabic literature in terms of openness and closedness clearly indicates the interrelations between the ending and the model of the textual reality, and the interrelations between this model and the extra-literary reality. It seems that when the historical, and especially the political and the social reality slaps writers across the face and stands before them in all its might and immediacy, they do not remain indifferent and write a literature with optimistic, promising, and closed endings; and vice versa: a text with a model of reality which does not relate to a well defined piece of history ends with a more open type of ending and becomes a closure in the reader.

\section{Introduction: What is closurization?}

Before embarking on our discussion we should refer to M. Torgovnick, who points out the vital distinction between the term "ending" and the term "closure." The first indicates the boundaries of the final, defined part of the text (section, paragraph, scene, chapter, page, sentence, etc.). The second designates the process whereby the literary text reaches a suitable conclusion, which is satisfactory and proper, or at least which the author hopes and expects will be satisfying and proper. In this sense closure includes ending. ${ }^{1}$ The ending of a literary work should receive special attention in the writing and reading processes alike. From the reader's point of view the ending of the literary work is the most salient part which remains carved in the memory, perhaps more than any other textual datum or part. ${ }^{2}$ This is not just because this is the part closest to the reader (in terms of time and space during reading) but also because the closure of a literary text is characterized by the natural and poetical devices of organization and construction. These are in fact the elements that lend order, importance, and significance to the

\footnotetext{
${ }^{1}$ See Mariana Torgovnick, Closure in the Novel (Princeton: Princeton University Press, 1981), pp. 6-7.

${ }^{2}$ See Alison Booth (ed.), Famous Last Words: Changes in Gender and Narrative Closure (Charlottesville and London: University Press of Virginia, 1993), p. 2.
} 
entire plot. ${ }^{3}$

Many scholars agree about the difficulty in finding a clear and accurate reply to the question of where the opening of a literary text ends and where its ending begins. Moreover, these concepts should not be discussed in the context of independent textual units detached from the body of the text, but through general examination of all relationships with other textual data. ${ }^{4}$ Discussion of closure, then, is interpreted as an attempt to discuss the literary work in its entirety: the opening, the middle, and the end, the linguistic and metaphoric elements and style in general, the thematics, the context, the author, the reader, the genre, etc. It is indeed an attempt to re-create or reexperience the entire literary work. ${ }^{5}$ The all-embracing and widely extensive

${ }^{3}$ See Peter Brooks, Reading for the Plot: Design and Intention in Narrative (New York: Knopf, 1984), p. 94.

${ }^{4}$ See Arnold E. Davidson, Conrad's Endings: A Study of the Five Major Novels (Ann Arbor, Michigan: UMI Research Press, 1984), p. 1. It is commonly believed that the closure of a literary text is a relative matter: see Barbara Hernstein Smith, Poetic Closure: A Study of How Poems End (Chicago and London: The University of Chicago Press, 1968), pp. 196; 211 n. 22. This is not a defined, clear, and conventional textual element. According to Jagendorf, the closure of a literary text is an organic and aesthetic part of the text, and any separation between the ending and the body of the work is artificial by definition: see Zvi Jagendorf, The Happy End of Comedy: Jonson, Molière, and Shakespeare (Newark: University of Delaware Press; and London and Toronto: Associated University Press, 1984), p. 11. According to Hillis-Miller, it is also extremely difficult to point to an exact beginning and closure of a narrative work: see Davidson, p.1. Lanham believes there is no conventional and common closure as there are no such openings and middles; such a division is problematic: see Deborah Roberts, Francis Dunn, and Dan Fowler (eds.), Classical Closure: Reading the End in Greek and Latin Literature (Princeton: Princeton University Press, 1997), pp. 11, 13.

${ }^{5}$ See Torgovnick, pp. 6-7. In this context, Dunn believes that it is difficult to discuss terms of closure using a defined theoretical terminology since the concept may be discussed from any theoretical angle: see Francis M. Dunn, Tragedy's End: Closure and Innovation in Euripidean Drama (New York and Oxford: Oxford University Press, 1996), p. 9. According to Dunn, it is a kind of mixture of several aspects and approaches, which fosters a multi-directional discussion: see Roberts, Dunn, and Fowler, p. 83. Fowler cites studies on closure arguing that it should be discussed in the cultural context, observing the genre of the given text, its specific theme, and its formal shape (p. 210). In the same vein Bruckner believes that in discussing closure we should also discuss the relationship between the text and the general reality. This discussion, according to Bruckner, can ramify in three directions: discussion of the end of the plot, discussion of contextual closure (in the extra-literary reality), and 
character of closure allows us to refer to the concept as closurization. The use of this term is meant to illustrate that closure is not limited or determinate, and it cannot be autonomous by definition. It is a subject for complex interdisciplinary study and can be treated from many aspects and angles. ${ }^{6}$

This paper makes use of most of the mentioned approaches, separately or combined, as manifested in a variety of theoretical studies conducted in recent years on the subject. It seeks to introduce an integrated model that takes the relevant hypotheses from the above diversity of approaches, thus allowing a multi-directional and inclusive perspective. Eventually, all the approaches somehow relate to the complex relationship of context, author, text, and reader. This relationship is displayed, as detailed in the following section, by stressing specific components. The system is examined in modern Arabic fiction from the 1950s. This is also the period when Arabic literature began making marked changes in all domains, both in content and in form.

discussion of the reader's position, education, experience, and approach: see Matilda T. Bruckner, Shaping Romance: Interpretation, Truth, and Closure in TwelfthCentury French Fiction (Philadelphia: University of Pennsylvania Press, 1993), pp. 200, 214. The determination of closure in a literary text is a question of thematization, according to Lanham: see Roberts, Dunn, and Fowler, p. 16. The thematization of a literary work is a complex, multi-directional, and inter-disciplinary issue. All these scholars indicate contextual effects on processes of literary creation: the cultural, social, economic, political, personal, and psychological background of the author. As stated by Smith, the closure of a literary text can be discussed in inclusive historical terms: see Smith, p. 234. Like Bruckner, Torgovnick believes that discussion of closure is multi-directional and three-dimensional, and it necessitates general consideration of the shape of the work itself, the prejudices of the author, and the reading experience: see Torgovnick, p. 12.

${ }^{6}$ Numerous study methods and methodological approaches can join together in an inclusive discussion on this topic, for example, as follows. The formal-structural textual approach refers to the connection of the ending to the opening and to previous textual data, and to location of the ending; to its type, and its connection to the central character-hero, semi-hero, anti-hero. The communicative approach considers the connection of the ending with the theory of gaps, the reader's role, and its place in the completion and interpretation of the ending. The functional approach concerns the connection between the ending and the thematics of the text, and the relation between the closure and political literature and commitment in general. This approach is based on the purpose of the text and has an affinity with the realistsocialist school. The social approach addresses the relation between the closure and the extra-literary, socio-economic reality. The historic approach looks for closure, for example, in the classical Greek play, the nineteenth-century novel, etc. Combinations of these approaches are of course possible, including all or some of them. 
The concept of closurization, the name proposed for the integrated model underlying our discussion of closure in modern Arabic fiction, consists of three main parallel levels combined into one:

1. Examination of the ending of the literary text: its boundaries, its shape, its type, its position, and its functioning in the intra-textual relationship, for example, between the beginning and the ending, or between the ending and the central character of the text.

2. Examination of the ending in context, the effect of extra-textual factors on the shape and identity of ending in the text; such factors are the historical, social, political, and cultural reality, etc. This reality directly affects the author, his/her beliefs, his/her identity, and his/her world-view, and this in turn affects the text written by him/her, including the ending.

3. Analysis of the closure in a communicative-literary context. This is an examination of the reader's position and role in the determination of an ending to a given text and in the determination of the general meaning of the closure.

The closurization model introduced here is in fact a summary of various studies on this subject. ${ }^{7}$ This is the most inclusive, authentic, and reliable model, one that can answer most possible questions about the closure of a literary text. The dearth of research on this subject in the field of modern Arabic literature indicates the selection of the triple model as a methodical basis that promotes a panoramic and comprehensive picture.

The kinds of closure of literary texts are commonly divided into two main opposite types: closed and open. ${ }^{8}$ This distinction is not well defined or unequivocal, and therefore has become subject to debate. The dichotomy is one between two poles, so to speak, of closure, connected by an entire continuum of types. These can be used in variations and combinations, which themselves create somewhat problematic closures. ${ }^{9}$ The closed, classic closure provides well defined answers and solutions to all the questions and

\footnotetext{
${ }^{7}$ The triple model, as shown here, underlies the work of several scholars: see Torgovnick, p. 12; Bruckner, p. 214.

${ }^{8}$ It seems that the first to propose this dual division was U. Eco: see Umberto Eco, The Role of the Reader: Explorations in the Semiotics of Texts (Bloomington and London: Indiana University Press, 1979), pp. 8-10, 47-66.

${ }^{9}$ According to Hillis-Miller we cannot clearly distinguish a closed from an open ending: see Davidson, p. 2. Torgovnick believes that a problem exists concerning the terms "closed" and "open" closure, since it all depends on the reader's perception: see Torgovnick, p. 208; see also Peter Haidu, "The Semiotization of Death: Open Text or Closed?" Style 20, no. 2 (1986): 221.
} 
problems arising in the body of the text. As stated by Morgan, this type leaves no room for more questions. The text is closed since there is nothing to add to it. ${ }^{10}$ Broad consensus exists among scholars on the definition and significance of the closed closure. Although both the open and the closed closure may seem to depend on the position, role, experience, and education of the reader himself/herself, as previously mentioned, an open closure is defined as the absence of answers and solutions to questions and conflicts developed in the body of the text. ${ }^{11}$ A closed closure demands primarily a clear demarcation of the ending in a text and its link to the other parts of the text. A closed closure is then an approach and a conception of writing. If it is a conclusion, it is convenient for this conclusive closure to rely on specific literary techniques which impart to it the role of the text's spokesman. The relationship between the closed ending of the texts and these literary techniques is based first on the principle of consent and completion. When these specific techniques play the role of direct writing and explicit design of the general significance of the text, the ending has the role of confirming this approach, supporting the textual significance, and complementing it by means of a clear and condensed conclusion. This closed ending then turns into a closed closure, and the entire text becomes a closed text. Parallel to this, the open closure, which has been given various names and denominations, is in fact the inverse of the closed closure. The contrast between "closed" and "open" allows us to treat these two types as opposites, in both the applied and the theoretical respect.

Some scholars interpret this division-into open and closed closure-as a distinction between a classical and a modern text, namely they perceive the open closure as a sign of modernism in literature. This distinction appears not to be so accurate. Undoubtedly, the open closure is one of the most conspicuous marks of modern literature, including Arabic. However, it is not entirely accurate to speak of the fixed relation between the closed closure and classical literature. ${ }^{12}$

\footnotetext{
${ }^{10}$ See Roberts, Dunn, and Fowler, p. 18; Smith, p. 2; Helmut Bonheim, The Narrative Modes: Techniques of the Short Story (Cambridge: D.S. Brewer, 1982), p. 119.

${ }^{11}$ See Robert M. Adams, Strains of Discord: Studies in Literary Openness (Ithaca, New York: Cornell University Press, 1958), p. 13.

12 For details about the correlation between classical literature and closed closure and between modernism and open closure, see Haidu, p. 22; Alan Friedman, The Turn of the Novel: The Transition to Modern Fiction (London and New York: Oxford University Press, 1966), pp. 179-180; Bonheim, p. 120; Booth, p. 347. But
} 
The determination of the kind, position, and significance of the closure of a literary text is first a function of reading and interpretation. For example, what is considered a semi-closed closure by a certain reader may be considered super-closed by another one, and vice versa. Since the position and role of the reader are a function of the type of closure in a literary text, types of closures are found which indeed allow more liberty to readers in the process of reading than other types do. However, in general the reader's role and position in determining the type and significance of a closure is central and indisputable. ${ }^{13}$ The different reactions of two readers to the same closure of a certain text constitutes outright evidence that the nature of this relation primarily results from a choice, and any choice entails a certain type of judgment and stance-taking. Thus the closure of a literary work is the chief part of the text constituting the convergence point between the author and the reader. For both, this is a source of taking a stand on the extra-literary reality and on the world in general. The determination of the closure's position in a literary text is overshadowed by the conflict over domination waged between the author and the reader. When the author constructs a closed closure to a work, this signifies the intention to retain exclusive control of the text and its general meaning. On the other hand, constructing an open closure indicates a desire to allow the reader to participate in the creation of the general meaning of the work and turn him or her from a consumer of the closed closure to an active participant in the production of a closure. ${ }^{14}$

other scholars believe that there is no difference between classical and modern literature in use of closure: see Torgovnick, p. 202; David H. Richter, Fable's End: Completeness and Closure in Rhetorical Fiction (Chicago and London: The University of Chicago Press, 1974), p. 3. We should be similarly cautious about the connection between these types of closure and certain genres. A basic difference is commonly believed to exist between poetry on the one hand and drama and prose on the other: see Roberts, Dunn, and Fowler, p. 210. Some scholars contend that poetry is more disposed to open closure (or anti-closure, or non-closure, or hidden closure) than to closed: see Smith, p. 244. The relationship between closure and literary genre is highly relevant, and it is most apposite in the discussion of modern Arabic literature.

13 On the reader's status in a literary communication process: see Ibrahim Taha, "The Literary Communication Pact: A Semiotic Approach," Semiotica 114 (1997): 131-50.

${ }^{14}$ An open literary work-based on an open ending-depends principally on the reader, according to Adams, p. 208. Smith states that the closure in poetry depends first on the reader him/herself: see Smith, p. viii. The reader's position in general, according to Torgovnick, wins special and serious attention: see Torgovnick, pp. $15-19$. 


\section{Open ending and open closure}

In this category the reader's position is particularly strong, both in the definition of the ending of the story "Li-mādhā tạra al-" uṣfūr?" (Why Did the Bird Fly Away?) by Jamāl al-Ghītānī15 and its meaning. The story's ending is not in its "natural place" in the last part of the text, which makes it difficult for the reader to deal with the text in terms of channeled, stable, and known linearity. This difficulty makes the reader's task remarkably interesting, slow, hesitant, and enthralling.

The story, which describes a little child who declares that he wants to kiss everything he sees, is divided into seven parts, each marked and numbered. In the seventh and last part the child, Muhammad, expresses his desire to kiss a bird that has hopped onto the balcony of his house. But this bird has flown far away and Mīdū, as the boy is nicknamed, asks why the bird flew away. This narrative cannot be said to have a chronological sequence, and the thread connecting its seven parts is the kissing motif, the desire to kiss everything. This motif is emphasized and recurs throughout the story. The use of a motif instead of a chronological sequence weakens the realistic identity of the text and reinforces its conceptual identity, as we shall see. The lack of a distinct chronological succession allows the reader to treat the story as a complete whole, and the classical triple division into beginning, middle, and end seems irrelevant here. The reader feels that it is possible to begin with any of the seven parts of the story. As any part can function theoretically and principally as an opening of the story, each can equally function as an ending to the story, especially those parts in which Mīdū cannot kiss what he wants. Therefore, it is difficult to determine the exact limits of beginning and ending.

Mìdū, the central character, is sometimes able to fulfill his wish to kiss whom/what he wants. Sometimes he is not, and he has to make do with a kiss from afar in the air. Sometimes he fails completely, and then he is disappointed and cries. In the seventh part of the story he wonders at the fact that the bird flies away when all he wants is to kiss it. The final sentence closing the story is a question, which usually indicates lack of information. In addition, the question in this text syncopates mixed feelings of failure, disappointment, wonder, and repressed anger. While the question directly concerns only one thing, the bird, logically it concerns any other thing which Mìdū cannot kiss in the story. The same question can be moved to the end of the second part, or of the fourth part. Namely, the alienation of the bird,

\footnotetext{
15 Jamāl al-Ghīṭān̄i, Nafthat Maṣdūr (A Consumptive's Spitting) (Cairo and Kuwait: Dār Sữād al-Sabāḥ, 1993).
} 
which is chosen to finish the story, and its flight from Mīdū's attempt to kiss it, are not the only factors, in a general perspective of the text, in Mīdū's feelings of failure, disappointment, wonder, and repressed anger. This distinction means that the ending of the text does not close the plot, and apart from the central question posed by the text at the end of the story, why did the bird fly away? additional questions may be asked. These may be, why end the story with the bird, out of the entire range of people and things that Mìdū wanted to kiss? Why did the story not continue? Is there selectivity in the choice of things Mīdū wishes to kiss, or is the choice totally arbitrary? The last part of the story does not provide answers to these or other questions arising in the reader's mind during or after reading. The feeling is that everything is left open and nothing is closed. The lack of a chronological link seems to contribute to the lack of closedness and to the lack of conclusion of the narrative with an ending.

The closing sentence of the story and its title are the same, the question mentioned above. What is the title of a literary text? What is the logic behind it? What is its significance, what are its kinds, what is the relationship between it and the body of the text? Is it part of the opening? Is it a kind of pre-opening or a pre-closure, or is it a post-closure? These are legitimate questions which should be extensively examined in other studies. All these questions presuppose that the title is an integral part of the text. The title of our story, which is the sentence that closes the text, leads the reader, before entering into the body of the text, into a state of expectation and alertness since this title hints at a concealed, vague, and incomplete situation. The question means a gap, in Iser's terms. The question-title of the text prepares the reader for a condition of slow perceptual communication, inviting him or her to fill the gaps created by this question, which remains open even after the ending.

This is a title which is far from being conclusive, summative, leading, and hinting. At the end of the reading process the reader goes back to the title, but this time seeing it as an enigma or riddle. If in the first encounter with this question-title the reader naively believed an answer could be found in the text itself, by the time he or she reaches the ending it has become clear that this was wrong. This ending has not contributed to the solution of the riddle but has only made it harder. ${ }^{16}$ The ending, in this sense, goes back to

\footnotetext{
${ }^{16}$ Ending, according to Peter Brooks, should neither complete the plot nor provide unravelling for the whole complication. It may be offered by separate allusions throughout the text. See Elizabeth J. MacArthur, Extravagant Narratives: Closure and Dynamics in the Epistolary Form (Princeton: Princeton University Press, 1990), p. 4.
} 
the title, which is in fact the ending. Therefore the link between the title and the ending creates a feeling of circularity, which fosters a sense of openness and enigma, as when someone goes round in circles aimlessly, and always returns empty-handed.

The central character in the story is a child who seems and sounds naive, and who wants to have whatever his heart desires. However, from Mìdū's viewpoint it is only natural that he is so "naive" and "demanding." If we stick to Mìdū's consciousness, the ending is considered open and even super-open. Mìdū's wish to kiss the bird in the last part of the story is a natural, normal, and self-evident desire, and it is perceived as a sign of affection and longing for contact, even if he doesn't phrase his wish in this way. The bird's flight is an unexplained and unjustified act, so Mīdū feels disappointed and hurt. In Mīdū's place, we too would have difficulty answering the question why the bird flew away. As long as we remain attached to Mìdū's consciousness the situation remains unchanged. This is an enigmatic ending which the investigator cannot explain. Even if the main objective of this question is to describe a certain situation and place it on the public agenda - exactly as it is—-for discussion and debate, even then this aim does not constitute the final point, since it expresses longing for something which does not exist.

In other words, if we see the question itself as an aim and not as a means to achieve a definite answer, the ending of this text might seem to be a closed ending. However, this closedness is not real. It is nothing but makebelieve, since the question in the text, like any such question, can never function independently as a complete unit as its existence is contingent on a particular answer. The absence of an answer may also be considered a reply. In some cases, the question may be a manifestation of longing for something, which attests to absence and lack; a condition of lack or absence is an open reality.

Transferring the question posed at the end of the story from the status of means to the status of goal cannot be discussed from Mìdū's point of view but only from the reader's, since Mìdū seeks an unambiguous answer and a convincing explanation for a specific, personal, and well defined subject.

If Mīdū's desire to kiss is interpreted as a longing for communication, then communication is bi-directional and even multi-directional. The question posed by Mīdū at the end of the story may also be interpreted as a longing for communication. When Mīdū asks he expects an answer, and an answer can lead to a continuous dialogue. Therefore this question may also offer an opportunity for the beginning of an expected and longed-for dialogue. If the ending of the text is some kind of beginning of another occur- 
rence, the story ends with anti-closure; it is neither closed nor finished. ${ }^{17}$ Whether this question is a means or an aim itself, the ending of the story remains open. Both from an inner perspective, namely Mīdū's point of view as a textual given, and from an external perspective, namely the reader's point of view, the question at the end of the story is some kind of open invitation for discussion, which we cannot know will take place at all. Like any other invitation, this is just a beginning for an additional occurrence which is about to follow.

\section{Closed ending and open closure}

This category deals with an undefined, elusive, and even misleading ending. In textual terms, an in-depth analysis of this ending shows it is not as it appears to be at first sight. In such a case the reader has to be active in the definition of the "real" borders of the ending, in decoding the apparent circularity of this ending, and in interpreting the ending which seems to be inherently ambiguous.

One of the most salient signs of the ending in the story " $\mathrm{Za} \mathrm{a}^{\mathrm{c}}$ balāwī" by Najīb Mahfūz ${ }^{18}$ is the dimension of dualism, duality, and paradoxicalness, as will be shown later on. At the end of the text the major character returns to the same condition he was in at the beginning. This beginning makes the general structure of the story circular. At the opening to the story, right from the first sentence, the central character (the narrator) explicitly declares: "Finally I became convinced that I had to find Sheikh Zacbalāwī" (p. 137). With the final two sentences at the end of the story, he returns to the same opening sentence: "The truth of the matter was that I had become fully convinced that $\mathrm{I}$ had to find $\mathrm{Za}^{\mathrm{c}}$ balāwī. ... Yes, I have to find $\mathrm{Za}^{\mathrm{c}}$ balāwī” ( $\mathrm{p}$. 147). Before proceeding we must ask if a reprise of the beginning occurs in the ending. Namely, are the opening and the ending sentences uttered in the same conditions? Do they have the same meaning? Is the ending indeed circular? If so, what kind of circularity is it? Two possible answers to these questions arise.

The first answer is discussed in terms of an ending, not in terms of a closure, and it includes two opposite possibilities. By the first possibility this is a circular ending, which returns to the opening of the text, and it may be in-

\footnotetext{
${ }^{17}$ On the terms "anti-closure," stated by Smith, and "open-ended," stated by Adams: see Torgovnick, p. 6.

18 Najīb Maḥūz, Dunyā Allāh (God's World) (Cairo: Maktabat Miṣr, n.d.), pp. 121-34. For an English translation of this story, see Denys Johnson-Davies (ed. and trans.), Modern Arabic Short Story (London: Oxford University Press, 1967), pp. $137-47$.
} 
terpreted as a declaration by the author of his failure to realize his wish/ dream presented explicitly there. This failure justifies the titles "closed" for the ending and "anti-hero" for the narrator. The "circular-closed" ending leaves the central problem of the text unsolved. All questions about the possibility of finding Sheikh $\mathrm{Za}^{c}$ balāwī at the end of this exhausting journey remain open, and this compels the narrator at the ending to announce the continuation of the search. In light of this possibility, the opening and the ending may be regarded as being under the same conditions, having the same significance, and fulfilling the same role. The opening sentence, in fact, is stated as a final conclusion after the narrator/major character has experienced the search for Sheikh $\mathrm{Za}^{\mathrm{c}}$ balāwī; only after this experience must $\mathrm{Za}^{\mathrm{c}}$ balāwi be found. The opening sentence is therefore part of the ending, and it has been transferred from there to the beginning to create an artificial and planned circularity. This is a verbal-textual circularity, indicating a state of helplessness and a feeling of terminal closedness. This is in fact the condition of the narrator on the disclosed level of the text, as if he were going round in closed circles searching in vain for Sheikh $\mathrm{Za}^{c}$ balāwī. By this approach $\mathrm{Za}^{\mathrm{c}}$ balāwī would not be found even if the story and the author's search went on and on. If this circularity is merely verbal, it is artificial, imaginary, and tactical, namely the text has no genuine circularity.

This brings us to the second possibility: if we delete the opening sentence (which has been relocated from the ending) and begin the story without it, or with different phrasing, if we ignore the location of this sentence and the imaginary circularity created by it, we get the feeling of a linear direction of the ending. In sum, the opening sentence is not the result of the ending or a conclusion reached by the narrator at the end of the quest, but it exists before the quest has begun. Namely, the opening sentence fits well in the first paragraph beginning the story. The narrator becomes convinced of the need to find Sheikh $\mathrm{Za}^{\mathrm{c}}$ balāwi after realizing that modern conventional medicine cannot remedy his serious illness. Only then does he decide to embark on his quest for Za ${ }^{c}$ balāwì's medicine, and the story starts with this fact. According to this possibility the text starts from the beginning and not from the end, namely before the narrator's quest and not after it. This is a linear and horizontal beginning. The significance of linearity is openness. Theoretically, the linear direction allows the plot to continue, and continuity also means openness. Therefore, two opposite conditions apply here simultaneously. There is planned circularity, meant to create the feeling that everything has closed down and $\mathrm{Za}^{\mathrm{c}}$ balāwi cannot be found; on the other hand, the circularity is artificial, and in fact there is linearity which creates the feeling that everything is open since at the end the narrator proclaims his need to con- 
tinue the quest he has started. ${ }^{19}$

Both these possibilities are discussed on the textual level. The two interpretations of the ending, the declaration of failure and the declaration of going on with the quest, presuppose that the main and declared aim of the text (of the main character/the narrator) is inherent in the verb "to find" in its literal sense, namely really to find $\mathrm{Za}^{\mathrm{c}}$ balāwī. These two possibilities make the text closed and open simultaneously. The paradox exists within the text and is not a function of the reader's free interpretation. The text seemingly "proclaims" in advance two possibilities existing in the ending, and the reader has to choose one of them. The choice requires no intellectual involvement by the reader, only some limited technical activity.

The second possible answer, on the other hand, is also discussed in terms of closure, but the reader plays a more active part in the definition of the ending and in the structure of the closure, charging it with a significance it may or may not have. Let us begin with the definition of the limits of the text's ending. Does the ending center only on the narrator's emphatic declaration that $\mathrm{Za}^{\mathrm{c}}$ balāwī can be found? Or does it start at an earlier stage of the text? Perhaps the problematic encounter between the narrator and Sheikh $\mathrm{Za}^{\mathrm{c}}$ balāwi occurs when the narrator is asleep, which is the "real" ending of the story. The last two sentences of the story, in which the narrator declares his wish to go on with his quest, are simply the conclusion of this "real" ending. ${ }^{20}$ This possibility exists, is convincing, and is justified, considering the symbolic identity of the story and its Sufi charge. ${ }^{21}$ The question is how

\footnotetext{
${ }^{19}$ Ian Rutherford believes the text may provide a "false closure" in its end, that is, the text may mislead the reader by the impression that the text is completely going to end while the text creates the impression of continuity. See Roberts, Dunn, and Fowler, p. 58.

20 Susan Lohafer uses the term "preclosure" to deal with the text closure: "For me, paying attention to preclosure seemed just another way of applying theories of closure." Susan Lohafer ed., Short Story at a Crossroads (Baton Rouge and London: Louisiana State University Press, 1989), p. 249.

${ }^{21}$ For more details about this story and its mystical charge, and other works by Najīb Mahfūz, see Ami Elad, "Mahfuz's 'Za'balawi': Six Stations of a Quest," International Journal of Middle East Studies 26 (1994): 631-44; Menahem Milson, "Reality, Allegory and Myth in the Work of Najīb Mahfūz," Asian and African Studies 11 (1976): 157-79; Hamdī Sakkūt, "Naguib Mahfouz and the Sufi Way," in Ferial J. Ghazoul and Barbara Harlow (eds.), The View from Within: Writers and Critics on Contemporary Arabic Literature (Cairo: The American University in Cairo Press, 1994), pp. 90-98; Sasson Somekh, "'Za ${ }^{c}$ balāwī': Author, Theme and Technique," Journal of Arabic Literature 1 (1970): 24-35.
} 
this ending can be interpreted and explained. This is in fact an encounter in which one party sleeps and the other is awake. The first is in the world of dreams and the other is in everyday reality. It is interesting to observe that the narrator, who has a material identity in the text, is in the land of dreams, and $\mathrm{Za}^{\mathrm{c}}$ balāwi who is portrayed in the story as having the undefined, paradoxical identity of a mythical character or of a saint, is in the end chosen to represent reality, or at least to be identified with it during the encounter. Here apparently is an inversion of roles, a conspicuous sign of dualism and duality. It allows the author to treat $\mathrm{Za}^{\mathrm{c}}$ balāwi as a dream or merely as a conception, and not as a real, tangible entity. The narrator's dream is in fact a special kind of encounter between the narrator and $\mathrm{Za}^{c}$ balāwi in which the narrator can find him. The proof is that when he awakes $\mathrm{Za}^{\mathrm{c}}$ balāwì has disappeared without trace. In other words, $\mathrm{Za}^{\mathrm{c}}$ balāwī cannot be found in reality. The narrator, who is given the opportunity to move to a spiritual world, the land of dreams, manages to attain some kind of inner harmony, tranquillity, and peace. Namely, he manages to find "his" $\mathrm{Za}{ }^{c}$ balāwi, which is what he sought. However, on returning he understands that dreams cannot always be translated in terms of tangible reality.

This leads us to the central question at this stage of discussion: what exactly is the narrator's purpose-and the purpose of the text in general: is it "finding" Za $\mathrm{a}^{\mathrm{c}}$ balāwī, as he distinctly states, or is it just the process of looking for him? If the former, the narrator has failed and is doomed to be considered a typical example of the anti-hero. But if the intention is to make a fateful and significant decision, looking for $\mathrm{Za}^{c}$ balāwi and always aspiring to look for him, then we have here a significant example of a hero who decides to cling to life and to continue looking for answers to his problem despite the physical and mental difficulties, perhaps even because of them. ${ }^{22}$ This is a decision for life. In this interpretation $\mathrm{Za}^{c}$ balāwi is not a stable and unique target but much more. He is the faith and the hope which give one the power and the will to go on living despite the pain and torments one might endure: "This anguish is part of the medicine!" If the hidden intent of the narrator is to convince one to make the decision to go on with the search for $\mathrm{Za}^{\mathrm{c}}$ balāwī, regardless of the significance of $\mathrm{Za}^{\mathrm{c}}$ balāwī, be it religious, political, social, economic, or ideological, then the purpose of the text is not to find $\mathrm{Za}^{\mathrm{c}}$ balāwi but to look for him. In this, the narrator finally attains what he seeks. The ending of the text becomes closed and it provides answers to

\footnotetext{
22 On the interrelation between heroism and closure see Roberts, Dunn and Fowler, p. 99; Ibrahim Taha, "Șūrat al-bațal al-ḥadīth fī qiș̣a li-Muhammad 'Alī Ṭāhā," alKarmil 18-19 (1997-1998): 301-330.
} 
questions posed in the body of the text. All these conclusions stem from the reader's interpretation and do not constitute a technical choice between two textual elements, as was the case with the first answer. This interpretation is the outcome of complex and intense analytical and cognitive activity on the part of the reader. If the ending is interpreted as a "pure" textual datum, the closure is a function of literary communication between the reader and the text. At the end of this process the double and splintered attitude to the story's ending seemingly can be formulated, the narrator has or has not attained his goal, as synthetic and complex. Namely, if the process of discussing the ending-closure of the story theoretically allows the coexistence of two possible opposite answers we can say we have a closed ending and open closure. ${ }^{23}$

\section{Open ending and closed closure}

In this category the reader gets the misleading impression that the ending is open and fragmentary, lacking some essential textual data. The discussion of the ending of Yūsuf al-Qa'īd's novel al-Harb fì barr Mișr (War in the Land of Egypt $)^{24}$ will be conducted on three levels: definition of the ending in objective textual terms related to the investigation, which is in fact the narrative in the novel; definition of the subjective positions of the novel's characters, especially the position of the investigator towards the entire affair, since he is the closing character of the novel; definition of the expected position of the actual reader to the affair in the novel.

The investigator, entrusted with the task of narrating the last chapter of the novel, states in its final paragraph:

I tried repeating it to myself: 'That's the end of the story.' I stopped and said it again. Then I asked myself, 'But is it really the end of the story?'

I'd asked a question, and it deserves a satisfactory answer, comprehensive, final and convincing. Since right now I don't know the answer, I'll have to start looking for it. If I fail, I'll drive the question from my heart, and let it wander the length and breadth of the land of Egypt, searching for its own answer. And when the question sets out on its journey, I'll follow it with another question: 'Will it ever find the answer?' (Arabic pp. 158-159; English 182-183).

${ }^{23}$ This dual conclusion seems to confirm Hillis-Miller's observation. According him it is extremely difficult to distinguish between open end and closed end. See Davidson, p. 2.

${ }^{24}$ Yūsuf al-Qa ${ }^{c} \overline{1}$ d, al-Harb fì barr Miṣr (Cairo: Maktabat Madbūlī, 1991; 1st ed. 1978). For an English translation, see Yūsuf al-Qa ${ }^{\mathrm{c}} \overline{\mathrm{i}}$, War in the Land of Egypt, trans. by Olive and Lorne Kenny and Christopher Tingley (London: al-Saqi Books, 1986). 
This passage contains a clear declaration of an open ending. The narrative has not ended and the question still hasn't found an answer. Moreover, the investigator wonders if an answer will ever be found to this question. The ending seems open and is going to remain so, as the skeptical approach of the investigator/narrator bears witness to. From the above passage several questions emerge regarding the "exact" boundaries of the novel's ending 25 and the meaning of the investigator's/narrator's statement that the narrative hasn't ended yet. Do these last words of the investigator refer to the textual level of the novel, or more precisely, does he mean that the fabula of the novel hasn't ended, that some textual data are lacking? Or does he perhaps mean that he misses a certain degree of position taking and a conscientious attitude? Who then has to give an opinion, and who is required by the tragic ending of the novel to adopt a certain stand? All the characters in the text, each for his or her own reasons, avoid telling the truth in a clear and unambiguous manner at the right time and the right place. Even the scrupulous and humane investigator, the embodiment of justice, who conducts the struggle for truth and justice, acquiesces to orders from his superiors. This investigator knows well that there is a conspiracy among various factors, officials, and commanders in the civil and military administration, against the guard and his son. Does this knowledge cause the investigator to blame himself at the end of the novel because he could not take an independent stand, as his conscience urged him all the time? Does he torture himself because he submitted to his commanders, betrayed his conscience, justice, and the truth? Namely, is he the addresser and the addressee of these questions? 26 He asks himself these questions:

The man called down blessings upon me, blessings that were heartfelt and sincere. I was pleased that I'd made him happy, though I had no faith whatever in my ability to keep my promise. He saluted and left, wearing his reassurance like a coat of paint on a dilapidated house.

As I sat there, I asked myself if I wasn't a party to the whole thing, if I couldn't be considered the main perpetrator. I should have given my instructions independent of anyone else, and the case should have been kept separate from everything that's happening in our country now. I came back to the word 'must', forgetting that I have no authority to use it. Even if I'd given my instructions, would they have been followed? I doubt it—but just to give them would have brought me a bit of comfort and self respect in the days to come (Arabic p. 158; English p. 182).

25 According to Fowler, it is easier to determine the end of the beginning than the beginning of the end. See Roberts, Dunn, and Fowler, p. 21.

${ }^{26}$ It is, according to M. Fusillo, a perspective and voice ending. See ibid., p. 211. 
This confession by the investigator/narrator at the end of the novel clearly testifies to a completed and whole reality. The disaster that befell the guard and his son, which became a case for police investigation, is a textual reality whose details trickle out to the reader from the characters throughout the novel. It is quite obvious who are involved in this disaster, who are the villains and who the righteous. Additionally, all the details of the plot are made known to the reader from various viewpoints. So to which missing things does the investigator refer at the end of the novel? I am sure he does not mean textual details related to the plot but his own, private attitude, his inability to make a decision and give orders to punish the guilty and to do justice. If he were talking about missing elements in the plot he would not make harsh decisions and hurl painful and serious accusations against himself. Blaming himself would not be possible at all if all the threads of the case were tied together and closed. In that case the two passages that end the plot of the novel would constitute unambiguous evidence of a closed ending.

This feeling of an open ending created by the first quotation refers to a post-textual position which has to be taken concerning the disaster that occurs in the novel. The investigator is quite convincing in what he says, in his confession and his blaming himself. He also makes efforts to justify the constraints that caused him to be silent. His justification was the reality of the emergency during the October war in 1973. His realistic attitude aspired to present the reality as it was in mathematical terms, without trying to change it or embellish it by any intervention in the text. The model of the textual reality in the novel suits the extra-literary reality, a compatibility that evinces the wish of the hidden/syncopated author to ask hard questions even when dealing with the difficult reality of an emergency. Therefore, the imaginary openness of the ending, as portrayed in the first passage quoted above, refers to one aspect of a model of reality, the investigator himself, and through him the readers in general. By using this ending the implied author wishes to ask the reader the same questions that the investigator asks himself. Moreover, on second thought a stand is apparent at the end of the novel, not just data and textual details referring to the plot. How can we interpret the investigator's confession, with all the harsh things in it, if not by viewing it as a comprehensive stance formulated negatively? The investigator's self-blame in his monologue of confession is clearly a stance he adopts. The lack of an explicitly defined and proclaimed answer at the end of the novel cannot testify to the total absence of a reply. Instead of declaring it explicitly, directly, and bluntly, he prefers to formulate this position using different variations of showing. This showing is manifested in the use 
of various tangible pictures, big and small, from the spheres of sight, hearing, movement, speech, etc., as well as from the sphere of mental states using variations of confession monologues. The logic behind the employment of these techniques is convincingly to infect the reader with his sensory attitude and his judgmental stance toward the disaster in the novel.

Contrary to the position of Muhammad al-Bārdī on the ending of the novel, according to which we are dealing with an open ending, ${ }^{27} \mathrm{I}$ believe that we are dealing with a closed ending both on the level of objective textual data of the plot and on the level of the attitude and position of each character on these data. We should note that all the characters participating in the narration of the novel express themselves in the first person. The investigator, who finishes the novel, is convinced, as the reader easily observes, that all details of the case are complete. The reader is also convinced there is an evident and whole plot. The choice of the investigator to narrate the last chapter is correct, logical, and convincing in the literary-poetical respect. The role of the investigator is to examine data after their creation. Moreover, he is the authentic and reliable authority who is supposed to provide exact, true, and complete details of the case. The investigator's testimony, giving us a comprehensive, detailed, complete, and accurate picture at the end of the novel, despite the village headman's (al- 'Umda's) denials, is a binding and unimpeachable document. The feeling of openness at the end of the novel does not concern the plot but the trials and expectations of the implied author, who uses the investigator to allow the reader to participate and to affect his position. The reader's taking a position is an extratextual act, and it is a hoped-for wish. Moreover, the actual reader, who is an extra-textual authority, is not entirely free. After all, the implied author has invested efforts through the text to present the problem as an unequal struggle between the weak and the strong, between the villains and the righteous. What is left for the reader is "to choose" the option already chosen for him/her by the text. Namely, the wished-for future act is the only choice for the reader. Therefore, the closure of the novel is closely linked to the textual ending itself.

\section{Closed ending and closed closure}

In this category the reader is exempt from most assignments imposed on $\mathrm{him} / \mathrm{her}$ in the previous texts. Instead of the complex and difficult task of defining and interpreting the ending, the reader has to be content with the

\footnotetext{
${ }^{27}$ See Muhammad al-Bārdī, al-Riwāya al- ${ }^{c}$ arabìya wal-hadātha (Al-Lādhiqīya, Syria, 1993), p.144.
} 
limited role of identifying the predetermined meaning of the text, particularly its ending. Instead of being an active interpreter who undertakes some of the tasks which commonly belong to the writer, he or she occupies the status of a rather passive consumer.

In the opening of the transparently allegorical story "al-Numūr fī al-yawm al- "āshir" (Tigers on the Tenth Day) by Zakarīyā Tāmir ${ }^{28}$ we learn of the intention of a tamer to tame a tiger in ten days, and he promises to succeed in his task by means of the brutal method of starvation and gradual subjection. This promise, made in the first paragraph of the text before the tamer begins to implement his method, is unambiguous. This opening serves as a classical model: presentation of the place, the characters, the central and proclaimed objective of the text (taming the tiger), and presentation of the methods for achieving this objective. Namely, the opening situation indicates absence of gaps that may catch the reader by surprise or require greater efforts to fill them. In other words, this is a complete and well closed opening. ${ }^{29}$

I began by discussing the opening in order to examine its relationship to the ending. At the end of the story, the tamer's promise is fully and literally fulfilled, exactly according to the plan as presented. The tamer's task is undoubtedly accomplished, and the tiger has indeed turned by the tenth day into a tamed citizen. The question in this context concerns the defined boundaries of the ending. Is the tenth day the boundary of the ending? How should we treat the words and distinct promise of the tamer at the beginning of the story? According to the suppositions of Edward Said, does not an opening that promises a certain ending, which is finally fulfilled, imply the ending $?^{30}$ The ending hidden in the opening creates a feeling that we are dealing with a successful attempt at prediction. Prophesying means foreseeing what is to come next. In the terminology of literary scholars it is termed prolepsis. Prolepsis is effected by various techniques and skills such as

28 Zakarīyā Tāmir, al-Numūr fì al-yawm al- ${ }^{c}$ āshir (Jerusalem: Manshūrāt Salāh al-Dīn, 1979), pp. 54-58. For an English translation, see Zakarīyā Tāmir, Tigers on the Tenth Day and Other Stories, trans. by Denys Johnson-Davies (London, Melbourne and New York: Quartet Books, 1985), pp. 13-17.

${ }^{29}$ It reminds us of the role of the prologue in classical drama: see Roberts, Dunn and Fowler, p. 84.

30 See Edward W. Said, Beginnings: Intention and Method (New York: Basic Books, 1975), pp. 4-5, 41. See also Frank Kermode, The Sense of an Ending: Studies in the Theory of Fiction (New York: Oxford University Press, 1967), p. 148. 
association, hopes, exegesis/interpretation, and previous experience. ${ }^{31}$ The question is whether the opening, which uses these techniques, conceals the ending or declares it explicitly and precisely. The tamer's confidence in himself and in his rich experience allows him to imagine the ending of the story right from the beginning. It is difficult to perceive the promise given in the opening of the story as a mere hint of what is about to happen at the end. A hint is usually based on suppositions or on ungrounded interpretations, and it may be misleading. In our case, the reader learns that the ending at the termination of reading has already been explicitly set forth in the opening. Even in the middle of the story the reader may feel everything is going according to plan and everything is about to end as was promised in advance. This statement leads us to the belief that there is an ending scattered all over the text, including the beginning, based on the following logic: the opening presents a firm promise concerning a specific ending of the text; in the course of the text this promise is fulfilled in a gradual and safe way.

This gradation from the first to the tenth day turns the taming activities into a lengthy and set process. The reader is taken day by day, chronologically and in an orderly manner, to the tenth day, which constitutes the "crowning" of a prolonged act. Namely, the tenth day in itself should not be perceived as the boundary of the ending, which is commonly considered to provide the answers to the questions posed in the text. The answers are provided piecemeal and not all at once on the tenth day. Therefore, the tenth day is deemed to be a continuation of a slow and gradual closing process. It is one part of the ending, one link in a chain of continuous ending. The structure of the story's plot can be clarified by the following diagram seen through the tamer's eyes:

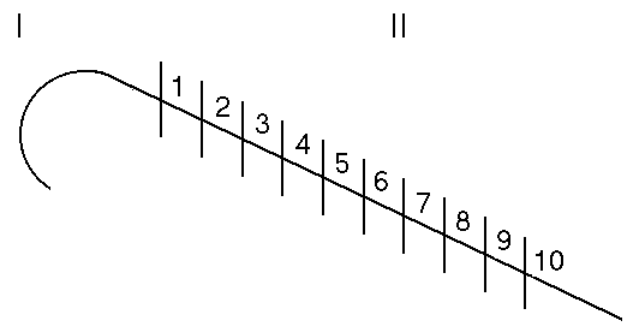

Figure 1

\footnotetext{
${ }^{31}$ For more details about this term see Shlomith Rimmon-Kenan, Narrative Fiction: Contemporary Poetics (London and New York: Routledge, 1983), pp. 46-51.
} 
This structure is made up of two main parts: the first part is the opening of the story, while the second refers to the taming process performed gradually over ten days. The beginning is the presentation of the problem, in the opening of the text, without indication incrementally of how the text has reached this problem or how the opening becomes the climax of the text. In other words, the text does not start from the beginning but from the middle (as distinct from Aristotle's classic pyramid) or even from the beginning of the ending. The entire second part of the plot structure, as can be seen in the diagram above, is a gradual ending of the text.

From the tiger's point of view, the structure of the plot is ascending and not descending:

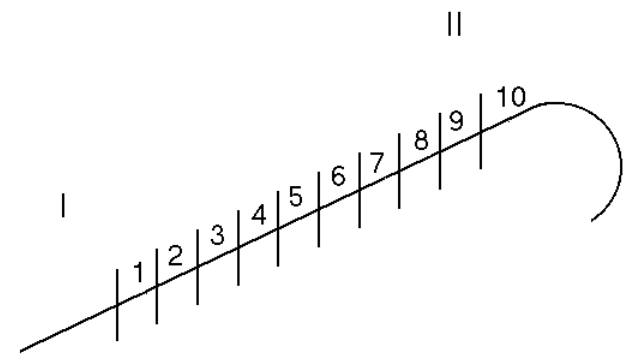

Figure 2

This diagram is the inverse of the previous one, in accordance with the difference between the tamer and the tiger. It shows that the story begins from the beginning and ends in a climax which demands a solution. However, the solution, as in the two previous texts, comes very close to the ending which appears as a climax. The solution required is an inversion of the condition reached by the tiger on the tenth day. The reader is not required to invest any additional efforts in active involvement and creative activity in order to reach this solution.

The reader's role in the first case, where the ending appears in the opening and is supported by the prolepsis technique, is to see how the ending is actualized. In the second case the reader has a feeling of being led to an ending which should be quite the opposite. In both cases the ending is strongly linked to the opening. If the ending appears in the opening we may speak of a certain kind of circularity, which creates a feeling of closedness. Namely, the ending verifies the opening. This closedness may indicate an extremely difficult extra-textual reality as reflected in the model of textual reality. The tiger in the story is analogous to various animals or even worse; being a citizen that does not function mentally, as turns out to be the case with the tiger 
as of the eighth day of taming, is worse than being a donkey that is aware of its situation, as evinced by the seventh day.

Consideration of citizenship and taming means a discussion in political terms. The politicization of writing feels at ease with the general message of the text being conveyed in a closed, direct, and absolute ending like the ending of this story. The politicization of a closed ending imposes the closure painfully on the reader, for if the tiger must be a citizen and go through various humiliating transformations it is not such a great honor being a citizen. Namely, it is not the tiger who is humiliated but the citizen, or the reader, any potential and actual reader in the Arab world. This insult to the reader/citizen is an attempt by the author to carry the ending of the story out of the text and cause strife between the citizens and the readers. This ending has become politicized through a conscious and intentional process.

If we perceive the taming process, which goes on for ten days, as a long ending scattered all through the text, two stages can be discerned. The first stage lasts from the first day to the seventh, while the second stage extends from the eighth day to the tenth. In the first stage the tiger goes through various transformations, in the course of which different and humiliating identities of other animals are imposed on him. In the second stage the tiger rises to an important rank in the humiliating taming process, namely the status of citizen. The second stage may therefore be referred to as the end of the continuous ending, or more precisely as the closure of the ending. The passage from the first stage to the second constitutes a clear, direct, and blunt political statement. Closure as a direct political statement is the prototype of a closed closure.

\section{Conclusion}

The discussion of these four categories clearly indicates the connection of the ending, its type, and its status in a literary text to the model of the textual reality, and the connection between this model and the extra-literary reality. The more this model is directly built on a historical fact or on a known historical conception, the more closed the ending of the text becomes, and as a result the more marginal the reader's status becomes; and vice versa. In these categories the reader's role was examined in the definition of the text's ending, in the identification of its type, and in an interpretation based on the dual distinction between open and closed and between ending and closure. In general we see that the two poles, ending and closedness, seem to be textual elements, more or less defined, "objective and independent." While the two poles, closure and openness, are more identified with the reader's position and role, they are mainly a function of the reader's "subjective" interpreta- 
tion. True, this dual division seems authoritative and categorical to a certain extent. But this seems to be the case when we deal with literature in terms which aspire to be "scientific."

The first category, the combination of an open ending and an open closure, indicates the participation of two authorities - text and reader-both in defining the text's ending and in "making" or "finding" the meaning of this ending, which imparts a feeling of closure to the entire text. The text builds for itself a model of a specific reality, which differs from the model of extratextual historical reality. The model of textual reality as reflected in alGhịtānī’s story "Why Did the Bird Fly Away?" is based on various techniques of defamiliarization and symbolism, which eventually make the text undefined and elusive, raising questions instead of answering them. This identity of the text invites the readers to treat it accordingly, using various skills such as basic knowledge, observation, analysis, experience, and the like.

The second category deals with circularity, which promotes the feeling of absolute closedness. On a deeper level of analysis this turns out to be circularity that does not provide answers to the problems discussed in the body of the text; or rather, the answer is provided but it is not unambiguous. This fact requires the reader to open the closedness of this circularity to various interpretations, as shown in the discussion of the story " $\mathrm{Za}{ }^{c}$ balāwī" by Mahfüz. Its model of reality is mainly made up of general elements of a known historical phenomenon in Egypt in particular and in the Arab world in general.

The third category concerns an opposite condition, namely an ending which seems open and gives the feeling of a broken and unfinished text. But closer reading shows that the open textual ending is in fact a closed and unequivocal closure. al-Qa ${ }^{c} \overline{1} d$ 's attempt at the end of his novel War in the Land of Egypt to create the strong impression that the text has not been completed, thus inviting the reader to create a closure of his/her own, is deceptive and misleading. The novel's model of textual reality is based both on the historical fact and the historical phenomenon. Thus it is difficult to fit an absolutely open ending to this model.

The fourth category, the combination of ending and closure based on closedness, is directly grounded in extra-textual phenomena known in the Arab world. In such terms, the ending of the text completes the basic elements of the fabula needed by the reader in order to comprehend the general meaning of the text. Moreover, this complete ending closes an available and undesirable textual reality and invites the reader to choose one option, which is the inverse, the desirable and the unattainable reality. The situation of total 
closedness of the ending creates a closed closure which the reader must accept without having to invest any special effort in interpretation, as reflected in Tāmir's story "Tigers on the Tenth Day."

Generally there is a salient trend in modern Arabic literature, manifested in most texts discussed in the article, to use an ending which indicates a strong desire for change. ${ }^{32}$ The attitude underlying this conception is the realistic approach, which does not comply with reality as presented in the literary text, whether directly and pronounced or less directly and less pronounced. The tendency not to comply with the textual reality, which reflects or represents the extra-textual reality, characterizes literary works whose the endings have gone through a process of politicization without attaching any negative meanings, at least not in this context. The extra-literary reality at the basis of the texts discussed here is an ugly one with numerous political, economic, and social aspects. It seems that when the historical, and especially the political and social reality slaps writers across the face and stands before them in all its might and immediacy, they do not remain indifferent and write a literature with optimistic, promising, and closed endings based on the approach of a committed literature; and vice versa: a text with a model of reality which does not relate to a well defined piece of history ends with a more open type of ending and becomes a closure in the reader. In addition to the strong position of the closed ending in modern Arabic literature, which provides well defined answers to historical reality, there is a clear tendency to reinforce the reader's status. A strong status of the reader in the issue discussed in the article means active participation on two levels: the "technical" level, namely the level of identification of the ending and determination of its limits inside the text (this is not always as easy as it seems); and the essential level, namely the level of ending interpretation (this is more essential than the previous one since it requires a link to all other textual elements and a relation to the extra-literary activity).

\footnotetext{
32 See Roberts, Dunn, and Fowler, p. 211.
} 